\title{
ПРОБЛЕМИ ЗМІСТУ ПРОФЕСІЙНОЇ ПІДГОТОВКИ МАЙБУТНІХ ПЕРЕКЛАДАЧІВ У ЗАКЛАДАХ ВИЩОЇ ОСВІТИ УКРАЇНИ ТА МОЖЛИВІ ШЛЯХИ ЇХ РОЗВ'ЯЗАННЯ
}

\section{Л. А. Олексієнко}

Кременчуцький національний університет імені Михайла Остроградського

вул. Першотравнева, 20, 39600, м. Кременчук, Україна. E-mail: oleksienko@ mail.ru

Досліджено проблеми змісту професійної підготовки майбутніх перекладачів у закладах вищої освіти України з урахуванням іiї шляху до європейської інтеграції. Проаналізовано педагогічні дослідження вітчизняних науковців щодо проблем змісту професійної підготовки перекладачів на сучасному етапі розвитку освіти України. Акцентовано увагу на відмінності усного та письмового перекладу. 3'ясовано, що відмінною особливістю української системи підготовки перекладачів від зарубіжної моделі $є$ те, що навчальні програми західних перекладацьких шкіл передбачають підготовку за двома різними спеціальностями: «Письмовий перекладач» і «Усний перекладач». Підкреслено, що українські заклади вищої освіти випускають універсального фахівця з перекладу. Визначено шляхи удосконалення професійної підготовки перекладачів в Україні.

Ключові слова:зміст навчання, професійна підготовка, перекладач, усний переклад, письмовий переклад.

\section{ПРОБЛЕМЫ СОДЕРЖАНИЯ ПРОФЕССИОНАЛЬНОЙ ПОДГОТОВКИ БУДУЩИХ ПЕРЕВОДЧИКОВ В УЧРЕЖДЕНИЯХ ВЫСШЕГО ОБРАЗОВАНИЯ УКРАИНЫ И ВОЗМОЖНЫЕ ПУТИ ИХ РЕШЕНИЯ}

\section{Л. А. Олексиенко}

Кременчугский национальный университет имени Михаила Остроградского

ул. Первомайская, 20, г. Кременчуг, 39600, Украина. E-mail: oleksienko@ mail.ru

Исследованы проблемы содержания профессиональной подготовки будущих переводчиков в учреждениях высшего образования Украины с учетом ее пути к европейской интеграции. Проанализированы педагогические исследования отечественных ученых по проблемам в содержании профессиональной подготовки переводчиков на современном этапе развития образования Украины. Акцентировано внимание на различия устного и письменного перевода. Установлено, что отличительной особенностью украинской системы подготовки переводчиков от зарубежной модели подготовки является то, что учебные программы западных переводческих школ предусматривают подготовку по двум разным специальностям: «Письменный переводчик» и «Устный переводчик». Подчеркнуто, что украинские учреждения высшего образования выпускают универсального специалиста по переводу. Определены пути усовершенствования профессиональной подготовки переводчиков в Украине.

Ключевые слова: содержание обучения, профессиональная подготовка, переводчик, устный перевод, письменный перевод.

АКТУАЛЬНІСТЬ РОБОТИ. Сьогодні Україна, вибравши шлях до європейської інтеграції та приєднавшись до Болонського процесу, здійснює модернізацію освітньої діяльності в контексті європейських вимог. У цих умовах значно підвищуються вимоги до якості перекладу, виникає необхідність удосконалення системи підготовки перекладачів. Дослідження особливостей підготовки перекладачів в умовах євроінтеграції дозволяє констатувати, що результати професійної підготовки майбутніх перекладачів в українських закладах вищої освіти на сучасному етапі розвитку індустрії перекладу та трансформації перекладацької професії мають забезпечувати сформованість у них таких компетентностей, які узгоджуються 3 узагальненими ключовими потребами ринку перекладацьких послуг i вимогами стандартів щодо їх надання [1].

Але, перебуваючи в стані продуктивних реформ i переорієнтації на якісне і результативне надання освітніх послуг, заклади вищої освіти, які готують перекладачів, мають певні проблеми, на яких наголошують українські науковці та викладачі. Серед основних проблем професійної підготовки перекладачів у закладах вищої освіти науковці називають необхідність удосконалення змісту навчання .

Мета статті полягає у висвітленні проблем у змісті професійної підготовки майбутніх перекладачів у закладах вищої освіти України та шляхи ї розв'язання.
МАТЕРІАЛ I РЕЗУЛЬТАТИ ДОСЛІДЖЕНЬ. Багато науковців і викладачів, які зацікавлені в підвищенні якості професійної підготовки перекладачів, указують на необхідність удосконалення змісту навчання та зміни навчальних планів (Зінукова Н., Іконнікова М., Корнієнко В., Левицька Н., Мартинюк О., Панов С., Поліщук Л., Чередниченко О., Черноватий Л., Семеног О., Шуппе Л. та ін.) і пропонують змінити набір дисциплін, які вивчаються, кількість аудиторних годин, переглянути блоки елективних курсів, приділити більшу увагу вивченню рідної мови тощо. Щодо цього, погоджуємося 3 думкою Ієронової I., яка зазначає, що, залишивши все краще, що було раніше у вищій школі (фундаментальна базова підготовка, гуманітарна спрямованість та ін.), необхідно подумати про те, щоб зробити її більш прагматичною, прибравши 3 процесу навчання все зайве. Як показує практика, студенти все одно не в змозі опанувати весь пропонований ім матеріал [2].

Аналізуючи зміст навчання майбутніх філологів галузевого перекладу 3 огляду на компетентнісний підхід, Черноватий Л. зазначає, що набір знань, навичок та умінь $\epsilon$ різним як для будь-якої галузі людської діяльності (автомобілебудування, сільське господарство, мовознавство тощо), так і для різних видів перекладу. Цей набір знань включає сукупність певних понять, термінів. Для підготовки майбутніх перекладачів важливо досліджувати конкрет- 
не наповнення предметного й термінологічного компонентів для кожної галузі, у якій здійснюється навчання студентів. Лише за наявності таких даних можна розробляти науково обгрунтовані навчальнометодичні матеріали для якісної підготовки майбутніх спеціалістів 3 міжмовного посередництва у конкретній сфері [3].

Окрім цього, науковець для визначення змісту навчання майбутніх перекладачів наголошує на необхідності окреслення обсягу необхідних для перекладача предметних галузевих знань, вивчення закономірностей вибору способів перекладу залежно від різноманітних чинників.

Аналогічної думки дотримується Левицька Н., яка зазначає, що в навчальному процесі підготовки перекладача необхідно ретельно відібрати та врахувати спеціальні знання, навички та професійні уміння, водночас звернувши увагу на творчий характер перекладацької діяльності [4].

На необхідності удосконалення змістового компоненту філологічної освіти, зокрема забезпечення інтеграції загальнонаукових, професійних, спеціалізованих знань, широкого впровадження інформаційно-комунікаційних технологій, елективних дисциплін фахового спрямування, розширення варіативної складової змісту за вибором студента та опанування спеціальної терміносистеми наголошують Іконнікова М., Корнієнко В., Максименко Л., Черноватий Л.,Яцишина Н.

На думку Максименко Л., одним із шляхів підвищення якості професійної підготовки перекладачів у закладах вищої освіти є побудова процесу навчання філологів-перекладачів на підставі інтегрованого підходу до змісту навчання 3 виконанням студентами інтегрованих практичних завдань, заснованих на автентичному матеріалі та спрямуванням на оволодіння фаховою компетентністю. Міжпредметна інтеграція повинна включати в себе взаємозв'язок змістовних аспектів різних навчальних дисциплін [5].

Досліджуючи зміст навчання майбутніх філологів галузевого перекладу, Черноватий Л. наголошує на необхідності використання міждисциплінарного підходу, необхідності синтезу на діяльнісній основітрадиційних і новітніх інформаційних технологій, коли види навчальної діяльності є об'єктом навчання і допомагають формувати загальне уявлення про професійну діяльність перекладача як про цілеспрямований, активний, тривалий процес пізнання [6-8].

На проблему роз'єднаності між навчальними дисциплінами та величезну кількість фактичного матеріалу, який пропонується засвоїти майбутнім перекладачам у межах кожного окремого предмета, указують Ієронова І., Іконнікова М., Мягкова О.

Мягкова О. вважає, що головні проблеми професійної підготовки перекладачів значною мірою обумовлені тим, що викладання різних теоретичних і практичних дисциплін усіх циклів часто «атомарне» і наслідком відсутності міждисциплінарних зв'язків $\epsilon$ «роздільне зберігання» студентами знань, здобутих у межах вивчення окремих навчальних дисциплін освітньої програми, відсутність цілісної картини (образу) майбутньої професії [6].
На проблемі обсягу навчального матеріалу, його наближення до реальних завдань професійного перекладача та періодичності оновлення; недостатнього обсягу фонових знань перекладачів вказують Мартинюк О., Поліщук Л.

Окрім зазначеного, Козак А. [7] і Поліщук Л. [8]наголошують на практичній відсутності декларативних знань (про ринок праці, вимоги клієнтів, норми поведінки та стосунки між перекладачем i клієнтом тощо), необхідності розмежування підготовки усного та письмового перекладача, так як усний і письмовий переклад суттєво відрізняються. У багатьох мовах ці види перекладу навіть позначаються по-різному: translation i interpretation в англійській, Übersetzung i Dolmetschung y німецькій, traduzione $\mathrm{i}$ interpretazione в італьянській.

Відмінні ознаки усного та письмового перекладу подано в табл. 1.

Таблиця 1 - Відмінні ознаки усного та письмового перекладу

\begin{tabular}{|c|c|}
\hline Усний переклад & Письмовий переклад \\
\hline $\begin{array}{l}\text { Вид перекладу, під час } \\
\text { якого оригінал і його } \\
\text { переклад існують у нефі- } \\
\text { ксованій (усній) формі, } \\
\text { що передбачає однокра- } \\
\text { тність сприйняття перек- } \\
\text { ладачем відрізків оригі- } \\
\text { налу і неможливість } \\
\text { подальшого зіставлення } \\
\text { або виправлення перек- } \\
\text { ладу після його виконан- } \\
\text { ня }\end{array}$ & $\begin{array}{l}\text { Вид перекладу, під } \\
\text { час якого оригінал і } \\
\text { переклад існують у } \\
\text { вигляді фіксованих } \\
\text { текстів, до яких пере- } \\
\text { кладач може зверта- } \\
\text { тися багаторазово, } \\
\text { поглиблюючи своє } \\
\text { розуміння оригіналу і } \\
\text { коректуючи вибрані } \\
\text { варіанти перекладу }\end{array}$ \\
\hline $\begin{array}{l}\text { Вид: синхронний, послі- } \\
\text { довний, абзацно-фразо- } \\
\text { вий, переклад з аркуша, } \\
\text { двосторонній переклад }\end{array}$ & $\begin{array}{l}\text { Вид: художній, } \\
\text { інформативний }\end{array}$ \\
\hline $\begin{array}{l}\text { Водночас може здій- } \\
\text { снюватися переклад кіль- } \\
\text { кох осіб (ораторів), які } \\
\text { мають різні стилі висло- } \\
\text { влювання та належать до } \\
\text { різних культур }\end{array}$ & $\begin{array}{l}\text { Текст для перекладу, } \\
\text { уже створений, пере- } \\
\text { важно одним автором } \\
\text { та одним стилем і } \\
\text { найчастіше змінам не } \\
\text { підлягає }\end{array}$ \\
\hline $\begin{array}{l}\text { Відбувається у реаль- } \\
\text { ному часі, часу для об- } \\
\text { думування фраз, їх побу- } \\
\text { дови і виправлення не- } \\
\text { має. Створення тексту } \\
\text { перекладу може відбу- } \\
\text { ватися або паралельно зі } \\
\text { сприйняттям оригіналу, } \\
\text { або після того, як завер- } \\
\text { шиться сприйняття ори- } \\
\text { гіналу }\end{array}$ & $\begin{array}{l}\text { Приперекладі є дос- } \\
\text { татньо часу для об- } \\
\text { думування фраз і } \\
\text { вибору найбільш } \\
\text { точних еквівалентів, } \\
\text { можна користуватися } \\
\text { довідниками та слов- } \\
\text { никами і кон- } \\
\text { сультуватися з більш } \\
\text { досвідченими про- } \\
\text { фільними спеціа- } \\
\text { лістами та колегами }\end{array}$ \\
\hline
\end{tabular}

Зважаючи на відмінності усного та письмового перекладу та погоджуючись 3 думкою Поліщук Л. [8], вважаємо, що кожна форма перекладацької діяльності, письмова чи усна, має особливості, які вимагають від перекладача необхідних професійних умінь і навичок, різних фахових здібностей, i, відпо- 
відно, різних підходів, технологій, методів підготовки перекладачів у закладах освіти.

Як зазначає Краєвська О., система вищої освіти перекладача в Україні досі віддає перевагу підготовці перекладача для виконання письмового перекладу (translation) на противагу усному (interpreting), що не відповідає сучасним реаліям роботи перекладача [9].

Відмінною особливістю зарубіжної моделі від української системи підготовки перекладачів $є$ те, що навчальні програми західних перекладацьких шкіл передбачають підготовку за двома різними спеціальностями: «Письмовий перекладач» і «Усний перекладач», причому умови прийому на відділення усного перекладу жорсткіші, ніж на відділення письмового перекладу. А українські заклади вищої освіти випускають універсального фахівця. Результатом цього $є$, як зазначає Поршнева О., недостатній рівень професіоналізму випускника, оскільки під час професійної підготовки відбувається змішання, по суті, двох різних спеціальностей, що вимагають у студентів-перекладачів формування специфічних професійно важливих якостей, умінь і навичок [10].

Досліджуючи фахову підготовку бакалаврів романської філології, Шуппе Л. зазначає, що в європейських університетах з першого курсу забезпечено пріоритет дисциплін фахової підготовки бакалаврів романської філології, які $€$ нормативними та обов'язковими впродовж всіх років навчання, у вітчизняних університетах вони здебільшого складають перелік дисциплін за вибором студентів, починаючи з третього курсу [11].

Зважаючи на особливості професійної діяльності усного та письмового перекладача, науковці вважають за доцільне, починаючи з 2-го або 3-го курсу, проводити відбір студентів на спеціалізації «Письмовий переклад» $\mathrm{i}$ «Усний переклад», що має відобразитися в навчальних планах, які б максимально враховували як майбутню професійну діяльність фахівців, так і сприяли б формуванню у них відповідних професійно важливих якостей.

Замислюючись над філософією спеціальності: переклад - це вузькопрофільність чи універсалізм, українські науковці схиляються до необхідності спеціалізації магістерських програм перекладу.

Магістерські програми професійної підготовки перекладачів у європейському контексті мають тенденцію до профільної спеціалізації.

Навчальні плани підготовки перекладачів другого освітнього рівня вітчизняних закладів вищої освіти вміщують цикли гуманітарної, фундаментальної, природничо-наукової, професійної та практичної підготовки, які поділяються на нормативну та варіативну частини (за вибором ЗВО та вибором студента).

Такий поділ відсутній в європейських університетах, там наявні курси, спрямовані на підготовку магістра з визначеною спеціалізацією.

На думку Мазур О., неможливо підготувати просто «перекладача» - такого собі «універсального солдата», здатного однаково професійно перекладати як твори художньої літератури, так і юридичні тексти разом із науковими трактатами [12].

Чередниченко О. зазначає, що «підготовка студентів за двома-трьома спеціальностями в межах одного навчального плану - це профанація вищої освіти» [13], адже неможливо «зліпити» гібрид «викладач двох іноземних мов + перекладач усього на світі», не вилучивши 3 навчальних планів цілі «масиви спецкурсів з фахової підготовки» [13], знизивши цим якість такої освіти.

Науковці Зірка В.В., Зінукова Н.В., Світлична О.Р. вважають, що тематичну підготовку перекладачів для роботи у певній галузі необхідно розпочинати лише тоді, коли студенти вже мають загальну професійну перекладацьку підготовку і володіють перекладацькими технологіями, а також мають певні знання з тієї галузі, у якій вони планують свою професійну діяльність. Таку підготовку може забезпечити курс елективних дисциплін у закладах вищої освіти. До того ж, важливим чинником $є$ необхідність передбачити закріплення знань у вибраній галузі за допомогою мови для спеціальних цілей (ESP) [14].

Але, зважаючи на вимоги роботодавців до перекладачів, однозначно неможливо відповісти на питання: якого перекладача повинні готувати заклади вищої освіти, оскільки роботодавець хоче мати фахівця з подвійною кваліфікацією (усний і письмовий), який широко обізнананий у споріднених і навіть у неспоріднених галузях знань. Для вирішення цього питання закладам вищої освіти необхідно застосовувати механізми ефективної взаємодії 3 роботодавцями, серед яких: вивчення потреб ринку перекладацьких послуг, залучення перекладачівпрактиків для проведення практичних занять 3 професійно зорієнтованих дисциплін, виконання проектів на замовлення роботодавця, залучення професійних перекладачів для оцінювання якості підготовки бакалаврів і магістрів перекладу тощо.

В основу традиційної системи освіти підготовки фахівців покладено два напрями в організації освітнього процесу. Як зазначає Пометун О., головною ознакою першого $є$ зміст навчання, тобто, насамперед, важливо, що саме викладається студентам. Другий підхід базується на обгрунтуванні процесу навчання, і головним є те, як викладається студентам той чи інший навчальний матеріал [15].

На думку Сорокіної О., ефективність фахової підготовки майбутніх перекладачів може бути досягнута завдяки наданню автентичного матеріалу із соціокультурним змістом у проблемній формі, забезпеченню діалогічного характеру навчальної діяльності на підгрунті ігрового моделювання ситуацій міжкультурної комунікації з урахуванням фасилітації, залученню студентів до самостійної комунікативно-пізнавальної діяльності з використанням механізмів педагогічної рефлексії [16].

Отже, акцентуючи увагу на проблемах змісту навчання, науковці визначають такі шляхи їх розв'язання: зміна ставлення викладачів до вимог програми навчання своєї навчальної дисципліни щодо перенесення акценту з кількості пройденого матеріалу на якість його засвоєння (головне завдання - не «пройти» матеріал, а навчити студента вчитися, спрямувавши його на діяльність); під час викладання практичних курсів основної (української), другої (третьої) іноземної мови 3 першого курсу 
орієнтація студентів на глибоке розуміння специфіки вибраної професії (практичний курс повинен давати студенту повну та цілісну картину мови, що вивчається, не повторюючи при цьому структуру шкільного курсу); координація теоретичних дисциплін для того, щоб студенти отримували єдину систему метамовних знань для використання їх у різних аспектах професійної діяльності.

Погоджуючись із думкою Биндас О., Зінукової Н., Ольховської А., Мартинюк О., Чередниченка О. та інших науковців, уважаємо, що оптимальним для української вищої освіти є взаємоузгоджене існування освітніх програм загального та вузькопрофільного спрямування. Збільшення спеціалізацій підготовки перекладачів є доцільним для рівня вищої освіти «Магістр». Зміст програм загального спрямування повинен бути розрахований на широку сферу працевлаштування перекладачів, тоді як програми вузькопрофільної орієнтації необхідно розробляти для задоволення потреб як окремих сегментів ринку перекладацьких послуг, так і враховуючи потреби ринку праці окремих регіонів, де функціонує заклад вищої освіти. Наприклад, навчати перекладачів за запитом конкретного підприємства, надавши можливості вибрати тільки ті професійнозорієнтовані навчальні дисципліни, знання яких необхідне для практичної діяльності в межах певного виробництва чи установи (юридичний переклад, переклад науково-технічних текстів, усний послідовний переклад).

ВИСНОВКИ. Розвиток ринку перекладацьких послуг потребує вирішення питань, які порушують українські науковці-перекладознавці, а саме: якою має бути програма підготовки перекладачів; чи має перекладач бути універсальним фахівцем або варто обмежити підготовку фахівця певною спеціалізацією; чи можливо підготувати перекладача, здатного однаково професійно перекладати як твори художньої літератури, так і юридичні і технічні тексти; чи можлива підготовка студентів за двома-трьома спеціальностями в межах одного навчального плану?

Шляхи удосконалення професійної підготовки перекладачів в Україні ми вбачаємо у збільшенні кількості освітніх програм підготовки перекладачів першого (бакалаврського) та другого (магістерського) рівнів, збільшенні частки вибіркових навчальних дисциплін у їхньому складі, які відповідають професійним інтересам майбутнього фахівця, приведенні змісту освітніх програм у відповідність до ринку праці, ринку перекладацьких послуг та їх оновленні із залученням фахівців цієї галузі.

Одним з ефективних шляхів розв'язання означених проблем,на нашу думку, є вивчення особливостей і використання позитивних аспектів підготовки перекладачів у закладах вищої освіти країн Свропейського Союзу, які є активними учасниками процесу європейської інтеграції в галузі освіти.

\section{ЛІТЕРАТУРА}

1. Амеліна С. М., Тарасенко О. Р. Орієнтація професійної підготовки перекладачів на вимоги міжнародних стандартів щодо реалізації перекладацьких проектів. Педагогіка формування творчої особистості у вищій $i$ загальноосвітній иколах. 2016. Вип. 51 (104). С. 60-65.

2. Иеронова И. Ю. Подготовка лингвистовпереводчиков в вузе. Высшее образование сегодня. 2005. № 8.C. 42-44.

3. Черноватий Л. М. Зміст навчання майбутніх філологів галузевого перекладу: компетентнісний підхід. Наукові записки Тернопільського національного педагогічного ун-ту ім. Володимира Гнатюка. Педагогіка. 2017. № 4. С. 126-134.

4. Левицька Н. В. Удосконалення системи професійної підготовки майбутніх перекладачів в університетах України на основі позитивного досвіду Німеччини.Молодий вчений. 2016. № 1 (2). С. 7477.

5. Максименко Л. О. Втілення сучасних підходів у процес формування у філологів-перекладачів компетентності у письмовому перекладі наукових текстів. Науковий часопис Національного педагогічного університету імені М. П. Драгоманова. Педагогічні науки: реалї та перспективи: зб. наук.праць. Київ : Вид-во НПУ імені М. П. Драгоманова, 2017. Вип. 58. С. 93-101.

6. Мягкова Е. Ю. Проблемы подготовки переводчика в современных условиях провинциального ВУЗа. Вестник Воронежского государственного университета. Лингвистика и межкультурная коммуникация. 2006. № 1. С. 119-122. URL: https://cyberleninka.ru/article/v/problemy-podgotovkiperevodchika-v-sovremennyh-usloviyahprovintsialnogo-vuza(дата звернення: 07.12.2018).

7. Козак А. В. Формування перекладацької культури та професійно важливих якостей спеціалістаперекладача: теоретичний аспект. Наукові праці Донецького національного технічного університету. Педагогіка, психологія $i$ соціологія. 2009. Вип. 3 (145). С. 31-35.

8. Поліщук Л. П. Основні напрямки професійної підготовки майбутніх перекладачів в умовах євроінтеграції. Вісник Житомирського державного університету імені Івана Франка. Педагогічні науки. 2017. Вип. 4 (90). С. 116-119.

9. Краєвська О. Д. Формування комунікативної компетентності майбутніх перекладачів засобами психологічного тренінгу. Наукові записки Тернопільського національного педагогічного університету імені Володимира Гнатюка. Педагогіка. 2016. № 1. C. 141-147.

10. Поршнева Е. Р., Зиновьева И. Ю. Подготовка профессиональных переводчиков в свете нового государственного стандарта. Высшее образование в России. 2011. №3. С. 63-69.

11. Шуппе Л. В. Фахова підготовка бакалаврів романської філології в університетах Іспанії та України: спільне і відмінне. Педагогічні науки: теорія, історія, інновачійні технології. 2017. № 1 (65). C. 280-290.

12. Мазур О. В. Критичний погляд на переклад як фах у системі української освіти. Наукові записки Ніжинського державного університету імені Миколи Гоголя. Філологічні науки. 2015. Кн. 2. C. 59-64. 
13. Чередниченко О. І. Про мову і переклад: мова в соціокультурному просторі, переклад як міжкультурна комунікація. К.: Либідь, 2007. 248 с.

14. Зірка В. В., Зінукова Н. В., Світлична О. Р. Професійна та галузева орієнтація у навчанні усному перекладу. Лінгвістика ХХІ століття. 2013. №. 2013. C. 83-88.

15. Пометун О. І. Дискусія українських педагогів навколо питань запровадження компетентнісного підходу в українській освіті. Компетентнісний під- хід у сучасній освіті: світовий досвід та українські перспективи (Бібліотека 3 освітньої політики): монографія. К.: «К.І.С.», 2004. 112 с.

16. Сорокина О. А. Теоретико-методологические основы системы формирования профессиональной направленности будущих переводчиков . Человек. Спорт. Медищина. 2006. №. 16 (71). С. 61 66.

\section{PROBLEMS OF THE CONTENT OF FUTURE TRANSLATORS TRAINING IN ESTABLISHMENTS OF HIGHER EDUCATION OF UKRAINE AND POSSIBLE WAYS TO THEIR SOLUTION}

\section{Oleksiienko}

Kremenchuk Mykhailo Ostrohradskyi National University

vul. Pershotravneva, 20, Kremenchuk, 39600, Ukraine. E-mail:oleksienko@mail.ru

Purpose. The article deals with the problems of the content of future translators training in Ukrainian higher educational institutions and the ways to their solution. Methodology. The research was conducted using systematic and interdisciplinary approaches, using general scientific theoretical methods: analytical, structural and functional analysis, synthesis, comparison, induction and deduction. Findings. The pedagogical researches of the Ukrainian scientists concerning the problem of the content of professional training of future translators in higher education institutions of Ukraine were analyzed. Scientists emphasize the necessity to improve the content component of philological education, in particular, the provision of integration of general scientific, professional, specialized knowledge, wide introduction of information and communication technologies, elective disciplines of professional direction, extension of the variable component of the content by the student's choice and mastering special terminology system. Special attention was paid to the question of delimitation of an oral and written translator preparation as oral and written translation differ significantly. Possible ways for solving the problems of translators training in Ukraine were determined. Originality. The scientific novelty lies in the fact that for the first time problems of the content of professional training of translators in Ukraine at the present stage and ways to their solution were considered in the article. Practicalvalue. The results of the research can be used to improve translators professional training for the first (Bachelor's) and the second (Master's) degree in higher educational establishments of Ukraine in the context of European integration processes. Conclusions. Future translators professional training efficiency can be achieved by increasing the number of educational programs for preparation of translators of the first and second levels, increasing the proportion of optional subjects in their content, bringing the content of educational programs in line with the labor market, the market of translation services and their updating with the involvement of specialists in this field.

Key words: training content, professional training, translator, oral translator (interpreter), written translator.

\section{REFERENCES}

1. Amelina, S. M., Tarasenko, O. R. (2016), "Oriientatsiia profesiinoi pidhotovky perekladachiv na vymohy mizhnarodnykh standartiv shchodo realizatsii perekladatskykh proektiv" [Orientation of professional translators training to the requirements of international standards for translation projects implementation], Pedahohika formuvannia tvorchoi osobystosti $u$ vyshchii $i$ zahalnoosvitnii shkolakh [Pedagogy of the creative person formation in higher and secondary schools], 2016, No 51 (104), pp. 60-65.

2. Ieronova, I. Yu. (2005), "Podhotovka linhvistov-perevodchikov v vuze" [Training of linguistic translators in high school], Vysshee obrazovanie sehodnia [Higher education today], 2005, No 8, pp. 42 44.

3. Chernovatyi, L. M. (2017), "Zmist navchannia maibutnikh filolohiv haluzevoho perekladu: kompetentnisnyi pidkhid" [Contents of training of future philologists in branch translation: competence approach], Naukovi zapysky Ternopilskoho natsionalnoho pedahohichnoho un-tu im. Volodymyra Hnatiuka. Pedahohika [The scientific issues of Ternopil Volodymyr Hnatyuk National Pedagogical University. Pedagogy], 2017, No 4, pp. 126-134.
4. Levytska, N. V. (2016), “Udoskonalennia systemy profesiinoi pidhotovky maibutnikh perekladachiv $v$ universytetakh Ukrainy na osnovi pozytyvnoho dosvidu Nimechchyny" [Improvement of the system of professional training of future translators in Ukrainian universities on the basis of the positive experience of Germany], Molodyi vchenyi [Young scientist], 2016, No 1 (2), pp. 74-77.

5. Maksymenko, L. O. (2017), "Vtilennia suchasnykh pidkhodiv $u$ protses formuvannia $u$ filolohiv-perekladachiv kompetentnosti u pysmovomu perekladi naukovykh tekstiv" [Implementation of modern approaches in the process of formation of translators-philologists competence of scientific texts rendering], Naukovyi chasopys Natsionalnoho pedahohichnoho universytetu imeni $M . P$. Drahomanova. Pedahohichni nauky: realii ta perspektyvy: zb. nauk. prats. Kyiv : Vyd-vo NPU imeni M. P. Drahomanova [Scientific journal of Dragomanov National Pedagogical University. Pedagogical sciences: realities and prospects: scientific issues. Kiev: Dragomanov NPU Publishers], 2017, No 58, pp. 93-101.

6. Miahkova, E. Yu. (2006), "Problemy podhotovks perevodchiika $v$ sovremennykh usloviyakh provintsialnoho VUZa" [Problems of preparing a translator in the modern conditions of a provincial universi- 
ty], Vestnyk Voronezhskoho hosudarstvennoho unyversyteta. Lynhvistyka $i$ mezhkulturnaia kommunikatsyia [Bulletin of Voronezh State University. Linguistics and Intercultural Communication], 2006, No 1, pp. 119-122, URL: https://cyberleninka.ru/article/ v/problemy-podgotovki-perevodchika-v-sovremennyhusloviyah-provintsialnogo-vuza (accessed 07, December 2018).

7. Kozak, A. V. (2009), "Formuvannia perekladatskoi kultury ta profesiino vazhlyvykh yakostei spetsialista-perekladacha: teoretychnyi aspekt" [Formation of translation culture and professionally important qualities of a translator-specialist: theoretical aspect], Naukovi pratsi Donetskoho natsionalnoho tekhnichnoho universytetu. Pedahohika, psykholohiia $i$ sotsiolohiia [Scientific issues of Donetsk National Technical University. Pedagogy, Psychology and Sociology], 2009, No 3 (145), pp. 31-35.

8. Polishchuk, L. P. (2017), “Osnovni napriamky profesiinoi pidhotovky maibutnikh perekladachiv $v$ umovakh yevrointehratsii" [The main directions of professional training of future translators in the conditions of European integration], Visnyk Zhytomyrskoho derzhavnoho universytetu imeni Ivana Franka. Pedahohichni nauky [BulletinofZhytomyrIvanFrankoStateUniversity. Pedagogicalsciences], 2017, No 4 (90), pp. 116-119.

9. Kraievska, O. D. (2016), "Formuvannia komunikatyvnoi kompetentnosti maibutnikh perekladachiv zasobamy psykholohichnoho treninhu" [Formation of communicative competence of future interpreters by means of psychological training], Naukovi zapysky Ternopilskoho natsionalnoho pedahohichnoho universytetu imeni Volodymyra Hnatiuka. Pedahohika [Scientific issues of Ternopil Volodymyr Hnatyuk National Pedagogical University], 2016, No 1, pp. 141-147.

10. Porshneva, E. R., Zinovieva, Y. Yu. (2011), "Podhotovka professionalnykh perevodchikov $v$ svete novoho hosudarstvennoho standarta" [Training of professional translators in the light of the new state standard], Vysshee obrazovanie $v$ Rossii [Higher education in Russia], 2011, No 3, pp. 63-69.
11. Shuppe, L. V. (2017), "Fakhova pidhotovka bakalavriv romanskoi filolohii $v$ universytetakh Ispanii ta Ukrainy: spilne $i$ vidminne" [Professional training of bachelors of Roman philology at universities of Spain and Ukraine: common and different features], Pedahohichni nauky: teoriia, istoriia, innovatsiini tekhnolohii [Pedagogical sciences: theory, history, innovative technologies], 2017, No 1 (65), pp. 280-290

12. Mazur, O. V. (2015), "Krytychnyi pohliad na pereklad yak fakh u systemi ukrainskoi osvity" [Critical view on the translation as a specialization in the system of Ukrainian education.], Naukovi zapysky Nizhynskoho derzhavnoho universytetu imeni Mykoly Hoholia. Filolohichni nauky [Scientific issues of Nizhyn Nikolai Gogol State University. Philological Sciences], 2015, No 2, pp. 59-64.

13. Cherednychenko, O. I. (2007), "Pro movu $i$ pereklad: mova $v$ sotsiokulturnomu prostori, pereklad yak mizhkulturna komunikatsiia" [About language and translation: language in socio-cultural space, translation as intercultural communication],Lybid, Kyiv, Ukraine.

14. Zirka, V. V., Zinukova, N. V., Svitlychna, O. R. (2013), "Profesiina ta haluzeva oriientatsiia $u$ navchanni usnomu perekladu" [Professional and branch orientation in the teaching of oral translation], Linhvistyka XXI stolittia [Linguistics of the 21st Century], 2013, No 2013, pp. 83-88.

15. Pometun, O. I. (2004), “Dyskusiia ukrainskykh pedahohiv navkolo pytan zaprovadzhennia kompetentnisnoho pidkhodu $v$ ukrainskii osviti. Kompetentnisnyi pidkhid u suchasnii osviti: svitovyi dosvid ta ukrainski perspektyvy (Biblioteka z osvitnoi polityky): monohrafiia" [Discussion of Ukrainian teachers on the introduction of a competence approach in Ukrainian education. Competence Approach in Modern Education: World Experience and Ukrainian Perspectives (Library for Educational Policy): Monograph], «K.I.S.», Kyiv, Ukraine.

16. Sorokina, O. A. (2006), "Teoretiko-metodolohicheskie osnovy sistemy formirovaniia professionalnoi napravlennosti budushchikh perevodchikov" [Theoretical and methodological foundations of the system of formation of the professional orientation of future translators], Chelovek.Sport. Meditsina [Person. Sport. Medicine], 2006, No 16 (71), pp. 61-66. 